\title{
ACKNOWLEDGEMENTS
}

The following individuals were instrumental to both the delivery of the July 2002 Bug Breakfast and to the evaluation:

\section{NSW Telehealth Initiative}

Kevin Garnham, Jill Hanvey, Kimberlee Isaac, and Debra Oong.

\section{Facilitators at the remote sites}

Ala'a Al Murieb, Allan Baker, Judy Lamb, Margaret Lesjak, Jeannine Liddle, Barbara May, Maggi Osbourn, Julianne Quaine, Sarah Thackway, Maree Tremble, and Marianne Trent.

\section{Members of the Centre for Epidemiology and Research}

Frank Beard, Margo Eyeson-Annan, Saru Gollakota, Marianne Jauncey, Leonie Neville, Barbara Telfer, and Maria Torres.

Lee Taylor developed the Access database and performed the analysis in SAS; Michael Giffin assisted in the production of this document.

\section{Others}

Many thanks to all the participants for their constructive feedback and to the reviewers of this report for contributing to its clarity and accuracy.

Bug Breakfast is videoconferenced each month through the financial support of the Health Protection Branch. 